been based, and indicates that, when the time comes to discuss larger systems of co-operation, Anglo-French collaboration will provide us with an invaluable store of wisdom on the community of ideas necessary for co-operation to be possible, and on the ends to which co-operation is desirable and possible. Already it shows us that some of the gravest weaknesses of the Treaty of Versailles and of the Covenant of the League of Nations will be avoided. The framework or constitution of the new world order will be attempted by a separate and subsequent act to the framing of the terms of peace. The declaration of March 28 may well come to assume historic significance in the evolution of world order, both as marking a stage towards the renunciation of absolute national sovereignty and in the linking of the distinctive political genius of two entire peoples in building up a system of co-operation to serve their own immediate purposes and also those of all other States subscribing to like ideals of law and justice, of freedom and humanity.

\title{
EDUCATION IN THE ARMED FORCES
}

$\mathrm{I}^{\mathrm{N}}$ $\mathrm{N}$ his review in the House of Commons on March 13, the Minister of War directed attention to developments in the provision of educational facilities for men in the Armed Forces. Mr. Stanley outlined the general scheme which is in operation under the ægis of the Central Advisory Council for Adult Education in H.M. Forces (Home Services), which was brought into being a few months ago. The Council is representative of organizations for adult education, and works in conjunction with regional committees set up by the vice-chancellors of universities or principals of university colleges in their own areas. The Board of Education acts as the medium through which the Central Advisory Council makes contact with the Admiralty, War Office, and Air Ministry, while the divisional inspectors of the Board take a similar part with the regional committees. The Central Advisory Council had appealed to the War Office for a sum of $£ 10,000$ "to be going on with", and help on a similar scale is being requested from the Admiralty and Air Ministry. The outcome of these applications is not clear and was not dwelt upon by Mr. Stanley in his statement, although the omission suggests that the applications have been at least temporarily shelved. It is essential that the existing situation should be clarified if misconceptions are to be avoided.

At its initial meeting, adequate testimony was reported by the Central Advisory Council to show that men and women in the Services are in pressing need of educational facilities of all kinds, including lectures and discussions, books and correspondence, and other services that have been fostered by adult education associations. The need of men and women in the Services for mental stimulation as well as for welfare and recreational facilities has frequently been neglected, a danger of which full cognizance must be taken to-day. This was not generally realized until the closing stages of the War of 1914-18, and not until 1920 was the Army Educational Corps founded as a permanent organization.

The objects of educational services were stated in an Army Order of September 24, 1918, to be : (a) to raise morale by indirectly providing mental stimulus and change, and directly by means of lectures on German methods, guns, etc.; $(b)$ to broaden and quicken intelligence both by stimulating a desire for study and by giving men a wider realization of their duties as citizens of the British Empire; (c) to help men in their work after the War by practical instruction, so far as may be possible, in their professions or trades. When later the various educational schemes were introduced, they were eminently successful ; their earlier introduction might have prevented much of the confusion that followed demobilization. Since that time, adult education has made such great strides that many men and women of the Forces to-day have been accustomed to lectures and discussions. The adoption of adequate educational measures is a matter of urgency, and one which should, if carefully planned, lead to the extension of democratic principles in a way which previously has been impossible.

The types of lectures that are likely to be most popular for men and women in the Forces have already been carefully investigated. The early experiments of the Central Advisory Council showed that the needs of the Services fall into three main groups: (1) a great demand for single lectures by authorities on such subjects as foreign affairs, history, exploration, literature 
and economics; (2) a great demand for short courses of about four lectures in places where men are stationed for two months or more ; and (3) an appreciable demand for classes in French and German. A scheme worked out by the staff of an evacuated school for men billeted in their area showed that the demands were in many cases more 'practical' than those described above. French and German were asked for by the majority, and next in order of popularity came shorthand and typewriting. Other requests were for mechanics, military geography and building construction. According to a reply from another battalion, contemporary history and current affairs were greatly in demand, while other topics that were repeatedly asked for included first-aid, physiology, psychology, criminology, police law and practice, etc. From the foregoing it may be seen that the provision of ad hoc courses would be insufficient and unsuitable for all the varied interests. The facilities provided should coincide with local demands so far as possible. Lecturers on scientific topics would be able to offer their contributions according to the regional demands.

The men in anti-aircraft and coastal defence units deserve particular attention. Many of them are desperately in need of educational facilities to relieve their long hours of monotony. It is heartening to find in Mr. Stanley's statement that for these units a more ambitious scheme involving continuous forms of education is under consideration. An official of experience in adult education is being seconded from the Board of Education and, in association with a military representative and an experienced welfare worker, is to prepare a scheme whereby educational and recreational facilities are to be developed side by side.

Considerable evidence is available to indicate the great importance of adequate library facilities to ensure the success of such a scheme, while the use of itinerant and peripatetic tutors would do much to encourage studies under adverse conditions.

The responsibilities devolving upon scientific workers to collaborate in any prepared schemes of continuous education would, if possible, be even greater than in peace-time. Astronomy, meteorology, horticulture and agriculture are subjects that have frequently been asked for by men in these isolated units, while other sciences would undoubtedly be in demand.

The supply of teaching personnel to satisfy these varying demands should not present any considerable difficulty; lecturers and tutors of all types would be more than ready to take an active part in any schemes of education that are prepared. The staffs of universities and university colleges have already expressed their willingness to contribute to the general scheme. It is to be expected that others who are interested in adult education would be available. A plea should also be made that the young school teachers who are already serving in the Forces should be made use of. Many of these teachers who have been conscripted would be glad to avail themselves of opportunities for getting practice in teaching; their adaptation to the elastic conditions that must inevitably arise should do much to increase their efficiency on their return to civil life.

Education in the Armed Forces is unquestionably a subject that is fraught with considerable difficulties. The one aim that should be constantly before our eyes is to discover the shortest method of bringing the War to a successful conclusion, and it is clearly recognized that in no circumstances must anything be allowed to interfere with military training or efficiency. But the contribution that mental alertness can make to military efficiency must also be fully grasped; its value to the peace and after is paramount. It is time, therefore, that the provisions made for educational services should be clearly stated, and a clear-cut policy adopted. To that end it is important that the schemes proposed by the Central Advisory Council should be carefully scrutinized. It is doubtful whether these schemes can be fully implemented until control is given to someone possessing the position, authority and drive enjoyed by Lord Gorell at the end of the War of 1914-18 in his capacity as head of the Army Educational Corps.

The establishment of a strong central organization would provide means whereby negotiations could be carried out with academic and professional bodies for the due recognition of the educational work done by men and women in the Forces. It could also arrange for the collection and distribution of books, films and equipment, etc. This central body would be able to co-ordinate the activities of the Central Advisory Council and the regional committees by the appointment of education officers in each battalion. The appointment of education officers would carry numerous advantages. They would be able to provide relevant information about the kind of educational services required in their particular units; they 
could give individual attention to all the educational problems confronting men drawn from primary and secondary schools, training colleges and universities. Thirdly, they would accompany their battalions when transferred from one district to another in Britain, and perhaps overseas.

It is important that educational facilities should not be limited to men and women in Great Britain. The extreme value of educational services in helping thousands of wounded soldiers towards recovery was strongly indicated by the Director-
General of Army Medical Services in 1914-18. The acceleration of recovery through the awakening of mental interest should be a commendable feature at the present time. There has already been a steady demand overseas for lessons in the French language, the provision of which has performed useful service in consolidating AngloFrench relations. The success achieved by the introduction of these classes should be sufficient encouragement for the development and extension of educational services overseas.

\section{ASPECTS OF THEORETICAL PHYSICS}

\section{(I) Lehrbuch der theoretischen Physik}

Von Prof. Dr. Georg Joos. Dritte Auflage. Pp. xviii + 704. (Leipzig: Akademische Verlagsgesellschaft m.b.H., 1939.) 24 gold marks.

\section{(2) Lectures on Quantum Mechanics}

By Prof. M. Raziuddin Siddiqi. Vol. 1. Pp. xi + 293. (Hyderabad: Osmania University, 1938.) 6 rupees ; $8 s .6 d$. net.

\section{(3) Atombau und Spektrallinien}

Von Prof. Arnold Sommerfeld. Band 2. Zweite umgearbeitete und erweiterte Auflage des "Wellenmechanischen Ergänzungsbandes". Pp. xi +820 . (Braunschweig: Friedr. Vieweg und Sohn, 1939.) 35 gold marks.

\section{(4) La Chimie Mathématique}

Vol. 1: Théorie Nouvelle de la Mécanique Statistique. Par Prof. Th. De Donder. Pp. 83. (Paris : Gauthier-Villars et Cie., 1938.) 40 franes.

(5) Hand- und Jahrbuch der chemischen Physik Herausgegeben von A. Eucken und K. L. Wolf. Band 3, Teil 2, Abschnitt 3-4: Die Boltzmannsche Statistik und ihre Modifikation durch die Quantentheorie, von A. Sommerfeld und L. Waldmann; Freie Weglänge und Transporterscheinungen in Gasen, von Karl F. Herzfeld. Pp. $\mathbf{x}+276$. (Leipzig : Akademische Verlagsgesellschaft m.b.H., 1939.) 28.80 gold marks.

IF mathematical physics can justly be considered as the prototype of international science, as a language understandable to all, independent of nation and race, the present volumes not only testify to this fact, but also at the same time to the opposite statement: that differences of personality are inextinguishable and apparent even in the presentation of the most objective of sciences.

The first two books are text-books intended for the use of teachers and students. (1) Joos' work is a remarkable attempt to compress the whole of mathematical physics, up to the most modern branches, into one single volume. The success of this attempt (in Germany) is proved by the fact that three editions have been published in a few (seven) years. I have read sections of all chapters, starting with the excellent introduction on mathematical methods of physics, passing over classical mechanics, relativity, electrodynamics, thermodynamics, to the modern parts which deal with statistical mechanics, structure of atoms and molecules, quantum and wave mechanics, and ending with nuclear physics-and everything is equally well presented, clear, short and interesting. It is an admirable book, which can be warmly recommended to all who can read German fluently. Numerous examples, the solutions of which are contained in an appendix, will be very useful for the beginner.

(2) The second volume, by Siddiqi, published in Hyderabad, India, is of about the same apparent size, but covers only a narrow field, quantum mechanics. The size is in fact deceptive as the number of pages, 287 , is very much smaller than that of Joos' book, 704, and the print more open ; the weight of the two volumes is in the ratio $1: 2$. I should have liked to praise this book also very highly, but I have to refrain as I could not help recognizing too many features of my own lectures in Siddiqi's work. In fact, the author was among my students in Göttingen and went later to Leipzig, where he attended Heisenberg's lectures. Since Heisenberg and I had only just parted after some years of collaboration when he was my assistant, there is little wonder that his lectures were rather similar to my own.

This origin of Siddiqi's book, which can be traced even to details of notation, is partly revealed by the author as he has dedicated it to Heisenberg. There are, of course, some new sections, short references to the neutron and 